\section{Dependência de drogas}

Sergio Dario Seibel e Alfredo Toscano Jr. Editora Atheneu, 2001, 560 págs. ISBN 85-7379-367-8

O livro "Dependência de Drogas" chega em boa hora. Poucos assuntos na área de saúde estão sendo tão discutidos no momento como os problemas associados ao uso de drogas. Este fato deve-se não só à alta prevalência do problema, mas também às questões sociais envolvidas (violência, criminalidade e moralismo).

Este debate, que recebeu um lugar de destaque na programação nobre da televisão, através da novela "O Clone", vem gerando inúmeras publicações sobre o tema. Essas publicações vão desde panfletos distribuídos em semáforos por exusuários, a fim de angariar fundos para suas instituições, até revistas científicas.

A saúde, especialmente a medicina, parece ter chegado atrasada a essa discussão. A dependência foi vista por muito tempo como um problema de caráter, social e moral, e, como tal, não merecia atenção da medicina. A visão do alcoolismo como doença é algo recente. Jellinek, em 1960, em seu livro "The Disease Concept of Alcoholism" trouxe grande contribuição para a mudança de concepção do problema. Como os que promovem a saúde não se faziam presentes, a própria sociedade começou a se movimentar para combater o problema. Surgiram então os modelos de tratamento sem a participação de profissionais de saúde: Alcoólatras e Narcóticos Anônimos, comunidades terapêuticas e instituições religiosas. É importante destacar que, apesar de todo o conservadorismo da igreja, os padres abriram as portas das igrejas para o problema antes da medicina.

Por isso, poderia se dizer que o estudo da dependência de drogas ainda é incipiente. Nós temos muito mais dúvidas do que certezas. Estamos passando de uma fase em que os estudos sobre o tema eram primordialmente baseados em uma compreensão psicodinâmica, que destacava as relações familiares como quase que exclusivamente determinantes da dependência de dro- gas, para um olhar mais detalhado do cérebro. Na atualidade, a dependência de drogas é considerada, para muitos, uma "doença do cérebro".

O livro de Seibel e Toscano consegue trazer as mais recentes informações sobre o assunto, mostrando os vários aspectos do problema e demonstrando que nosso país tem um corpo de pesquisadores/estudiosos no assunto que merece respeito. A maior parte dos capítulos é geradora de conhecimento e não só compiladora de informação.

Este livro apresenta uma visão ampla, sem ser superficial, do problema da dependência de drogas. São 56 autores de capítulos e 2 editores discutindo as várias áreas relacionadas à dependência de drogas. Poucas áreas da saúde podem propiciar uma discussão tão rica quanto a dependência de drogas. Neste livro encontram-se 15 diferentes áreas que vão desde a Psiquiatria ( 21 colaboradores e 2 editores) até a Antropologia e o Direito.

Este livro tem como grande mérito levar ao leitor especialistas que discutem os temas baseados em um modelo científico e sem preconceitos. Essa abordagem diferencia esse livro de outros que adotam um modelo de referência único, universal e que se diz capaz de responder a todas as perguntas. O livro, por sua abrangência, deve se configurar como uma referência na área.

André Malbergier Departamento e Instituto de Psiquiatria da Faculdade de Medicina da Universidade de São Paulo. 